\title{
Migrants/Refugees in Slovene Healthcare Many Open Questions and Some Possible Answers
}

DOI 10.17234/9789531756525.9

Uršula Lipovec Čebron

Department of Ethnology and Cultural Anthropology, Faculty of Arts, University of Ljubljana

Zavetiška 5, 1000 Ljubljana, Slovenia

ursula.lipovec@ff.uni-lj.si

Sara Pistotnik

Department of Ethnology and Cultural Anthropology, Faculty of Arts, University of Ljubljana

Zavetiška 5, 1000 Ljubljana, Slovenia

sara.pistotnik@ff.uni-lj.si

Based on the research conducted within the framework of the project "Together for Health - Skupaj za zdravje” led by National Institute of Public Health (2014-2016), the first part of the chapter presents several obstacles - legal and administrative barriers in formal access to Slovene public healthcare system as well as language and cultural barriers - that migrants/refugees face in the healthcare system in Slovenia. In the second part of our contribution, the authors discuss some approaches aimed at overcoming these obstacles that were implemented as part of the same project. Namely, a proposal for systemic changes on the level of legislation, an introduction of an intercultural mediator for women from the Albanian-speaking community in two Slovene healthcare institutions, a training course on cultural competence for healthcare workers and a selfevaluation tool for the measurement of the level of equity in the healthcare institutions. Through a critical analysis of these approaches, the authors try to show their advantages and limitations and to conclude this chapter with some considerations for future developments in this field.

Keywords: migrants/refugees, healthcare, Slovenia, obstacles, tools/strategies

\section{Introduction}

$\mathrm{H}$ eide Castañeda, together with Seth M. Holmes, James Quesada and other anthropologists (2015), suggests that when speaking about migration and health the questions of access to healthcare are the "most common structural factor explored in the literature" (Castańeda et al. 2015: 381). Moreover, the same authors recommend that in order "to make substantive improvements in health outcomes for migrants, migration must be understood as a key social deter- 
minant of health in its own right. Migration influences all other social relationships and is a lived experience that directly affects health and well-being" (ibid.: 386).

We argue that, in Slovenia, the "deterioration" of the once almost universal public healthcare system is most visible precisely in relation to migrants' access to healthcare. Research in this field (Rajgelj 2012; Leskošek 2013, 2016; Lipovec Čebron and Pistotnik 2018) shows the gradual encroachment of health rights for a growing number of people, first for migrants/refugees and erased citizens of Slovenia and later for many other social groups (precarious workers, homeless etc.). Different studies thus confirm that the initial diminishment of rights for migrants/refugees in Slovenia was a starting point for the gradual disintegration of the universal healthcare principle, which has in the last two decades lead to the diminishment of rights for other residents. Therefore, we can state that the insufficient and inadequate access to quality healthcare for migrants/refugees in Slovenia is not an exception to the rule. Namely, for some categories of migrants, it is embedded on the systemic level and has been developing from 1991 on, since the independence of Slovenia.

But in what way are the healthcare services insufficient and/or inadequate for this population? What kind of obstacles does it face? In what way could these obstacles be addressed? In the first part of the chapter, we will put attention on some of the crucial obstacles that migrants/refugees face when they search for healthcare in Slovenia. In the second part, we will focus on some possibilities of overcoming these obstacles - namely, changes on a systemic (legal, governmental) level, the introduction of intercultural mediators and interpreters in healthcare institutions, training in cultural competency for healthcare workers and a self-evaluation tool for the measurement of the level of equity in healthcare institutions. The main findings presented in this chapter are based on the research work carried out by an interdisciplinary team (composed of health care professionals, researchers in public health and medical anthropologists) that was part of the project "Towards Better Health and Reducing Inequalities in Health - Together for Health". The project was led by the National Institute of Public Health Slovenia and financed by the Norwegian Financial Mechanism 2009-2014. ${ }^{1}$

\section{Migrants'/refugees' obstacles in search for health}

It is well known that people from so-called marginalized groups are generally at a higher risk of health problems and suffer from more health-related issues (Kraševec 1996; Marmot and Wilkinson 2006; Holtz et al. 2006; Buzeti et al. 2011; Farkaš et al. 2011; Rostila 2013), while also facing more difficulties - due to linguistic, cultural, administrative, financial and other obstacles - when visiting healthcare

We thank the project leader Marija Magajne, MD, MSc, the leader of Work Package-Adults Jožica Maučec Zakotnik, MD, Simona Jazbinšek, Ivanka Huber and Jerneja Farkaš-Lainščak, $\mathrm{MD}$, for all their contributions. 
facilities compared to the general population (Marmot and Wilkinson 2006; Rostila 2013). In case of migrants/refugees, these barriers are even more problematic:

\begin{abstract}
"Although most migrants are healthy when they first arrive in their host country, they risk falling into poorer health compared to that of the average population because of the conditions surrounding the migration process (Smedley et al. 2003). These migrant groups are more vulnerable, due to their lower socio-economic status and the conditions of poverty they abandon are often to be re-encountered in their new host countries. This vulnerability is at times caused by traumatic migration experiences, by the feeling of exclusion in the place of arrival, and often by a lack of adequate social support due to the absence of integration and specific socio-health policies (Mladovsky 2009)." (HPH Task Force MFH 2014: 11-12)
\end{abstract}

Migrants' and refugees' health is exacerbated by the obstacles they encounter when trying to access health services: they tend to receive lower levels of healthcare compared to host country nationals due to the lack of awareness of services available, the absence of appropriate accessibility to services, and the negative attitude of staff in the delivery of health services (ibid.).

Previous research in Slovenia has confirmed that migrants/refugees often face cultural, linguistic, administrative, economic and other types of barriers within the healthcare system, resulting in lower quality healthcare services and unequal treatment (Brovč et al. 2009; Jazbinšek and Palaić 2009; Bofulin and Bešter 2010; Lipovec Čebron 2010a, 2010b; Bombač et al. 2017; Lipovec Čebron and Pistotnik 2018, etc.).

The inadequacy and poor accessibility of healthcare for migrants/refugees is also reflected in Migrant Integration Policy Index Research (MIPEX), a recently published comparative analysis of migrants' access to healthcare, which ranked Slovenia at the penultimate place among 38 other countries, alongside Croatia and Latvia and far below average even for Central Europe (MIPEX 2015). Similar are the conclusion remarks in the Country Report Slovenia (Ingleby 2017: 23):

"[F]ew of the incentives that have encouraged many other EU/EFTA countries to adapt their health systems to the presence of migrants are present. In Slovenia, indifference to the special needs of migrants was reinforced by the assumption - not always justified - that since most of them came from former Yugoslav republics, they would experience few linguistic or cultural barriers. [...] Although most legal migrants are included in the country's social health insurance system, the burden of additional complementary private insurance to cover co-payments and supplement the basket of services falls disproportionately on those on low wages - which is the situation of most migrants. Little is done to reduce the gap between health services and migrant users, either by adapting the services or signposting the way to them more clearly. As far as measures to achieve change are concerned, migrant health does not appear to be on the government's agenda, although academics and NGOs are active in this field." 
International evaluations as well as scientific research therefore show a lack of effort to facilitate access to the healthcare system for migrants/refugees with different legal statuses in Slovenia. Various programs that address these limitations are mostly project-based, and as such cannot replace systemic solutions and/or offer long-term success in this field. However, they at times present a good basis for experimentation with different approaches that could bring some progress towards more inclusive healthcare for this population. One of such projects was "Towards Better Health and Reducing Inequalities in Health - Together for Health". Its general objective was to reduce lifestyle-related chronic non-communicable diseases through upgraded and promoted preventive health programs and to establish new models and approaches that would reduce inequalities in health. The part of the project we are focusing on in this chapter had two phases: the assessment of the needs of various so-called marginalised or vulnerable ${ }^{2}$ groups among the Slovene population and the development of tools/strategies aimed at overcoming specific obstacles, which were detected in the assessment.

The findings of the assessment of needs were to some extend comparable to previous research (Brovč et al. 2009; Jazbinšek and Palaić 2009; Bofulin and Bešter 2010; Lipovec Čebron 2010a, 2010b). They were gathered through qualitative research, which was conducted between June and September 2014 in 8 Slovene cities $^{3}$ and their surrounding areas and included interviews with 121 individuals (healthcare workers, employees of public health institutions as well as different professionals from the non-governmental sector and users of healthcare services). The research was divided into three topics: first, the identification of vulnerable groups in Slovene healthcare system; second, the description of various legal, administrative and practical obstacles these groups encounter while accessing healthcare services; and third, the identification of possible solutions to overcome these obstacles.

The results of the research have revealed that migrants/refugees were perceived as the most vulnerable group in relation to health and healthcare (other groups that were mentioned were "homeless", "older people", "individuals with drug addictions", "unemployed", "people with mental health problems", "Roma" etc.). ${ }^{4}$

When using the term vulnerable groups we should be careful since the term itself can cause further stigmatisation. Equally justified would be the usage of terms marginalised, excluded etc. In this contribution we will use these terms interchangeably.

3 Koper, Izola, Ljubljana, Kranj, Sevnica, Novo mesto, Celje, Murska Sobota.

4 Besides migrants/refugees that were mentioned 31 times, interlocutors identified as "vulnerable group" also "homeless" (24 answers), "older people" (21 answers), "individuals with drug addictions" (17 answers), "unemployed" (17 answers), self-employed and precarious workers (17 answers), "people with mental health problems" (15 answers), "Roma" (14 answers), individuals with handicap (6 answers). 
Moreover, the qualitative research showed that among main obstacles migrants/ refugees (but also many other individuals from above mentioned groups) face in Slovene healthcare system are:

1. Legal and administrative obstacles in formal access to the public healthcare system: a) Limited or denied access to compulsory and/or complementary health insurance

The access to Slovene public healthcare system is organized through the health insurance scheme, which provides for two types of health insurance: compulsory and complementary health insurance. Compulsory health insurance, ${ }^{5}$ that is the basis for the financing of the healthcare system in Slovenia, ${ }^{6}$ is obligatory for Slovene citizens with permanent residence in Slovenia. The majority of Slovene citizens and migrants acquire their health insurance on the basis of employment, ${ }^{7}$ children and spouses can be insured as family members, whereas the local communities provide financial resources for socially disadvantaged individuals (citizens and migrants with permanent residence permits).

But compulsory health insurance does not cover all costs of the treatment (full coverage of costs is ensured only for children, pupils and students, up to age 26, who regularly attend school, and in the case of certain diagnoses and conditions) therefore second, complementary health insurance ${ }^{8}$ was introduced. This is voluntary and covers the difference between the percentage covered by the compulsory health insurance and the full price of health services. The insurance premium for complementary health insurance is to be paid by an individual (approximately 30 euros per month) and to acquire it, one has to have compulsory health insurance. If a person is lacking complementary health insurance, he/she needs to pay an additional sum out-of-pocket for the majority of medical services.

One of the most important findings of the above-mentioned qualitative research was that the Slovene health insurance scheme results in limited access to public healthcare system for people who are not insured through compulsory and/or complementary health insurance. Namely, some migrants/refugees (for example undocumented migrants, asylum seekers, unemployed persons with temporary residence permit without the legal right to compulsory health insurance) have severely

Compulsory health insurance is provided by the Health Insurance Institute of Slovenia, which is a public institution.

6 In 2014 compulsory health insurance contributions provided $68,1 \%$ of the health expenditure (Albreht et al. 2016).

7 This includes different types of self-employment. Besides, for some categories of people (prisoners, veterans etc.) the legal provisions enable health insurance on other basis but these categories are not prevalent.

8 The insurance can be arranged at three insurance companies. 
limited or denied access to compulsory health insurance so they can access health system only through necessary treatment. Moreover, the interlocutors stressed that migrants/refugees (but also other residents) with low income are in some cases unable to pay contributions for complementary health insurance and as a result avoid visits to healthcare institutions due to fear of additional out-of-pocket sums for treatment (see also Lipovec Čebron et al. 2015; Lipovec Čebron et al. 2016; Lipovec Čebron and Pistotnik 2018).

\section{b) Restriction of the right to necessary treatment}

Furthermore, the research confirmed that the right to necessary treatment - in principle accessible to all persons in need of urgent medical assistance on territory of Slovenia - is in some cases breached in practice. According to health legislation in Slovenia, urgent treatment should be free of charge and universally accessible to all people, regardless of their health insurance status. ${ }^{9}$ It includes a very limited scope of healthcare rights $^{10}$ (reanimation, first aid, etc.), life-sustaining treatment, and prophylaxis (measures designed to preserve health and prevent the spread of the disease). Yet various interlocutors in the qualitative research emphasized that many migrants/refugees experienced being denied access in urgent medical situations. The cause of this selectivity derives also from a series of obstacles that restricts access to necessary treatment and which were repeatedly mentioned in the interviews. First, although the definition of urgent treatment seems to be unambiguous, practise shows that it depends largely on the arbitrary assessment of health workers. As a result, urgent medical assistance varies greatly (ranging from very restrictive to very liberal readings), leading to a potential violation of this right (Lipovec Čebron 2010a; Lipovec Čebron and Pistotnik 2018). Secondly, the right to urgent treatment has been additionally limited due to changed admission guidelines in the last years. ${ }^{11}$ This is reflected in the introduction of a rather complicated administrative

9 Article No. 7 of the Health Care and Health Insurance Act (Zakon o zdravstvenem varstvu in zdravstvenem zavarovanju, ZZVZZ) provides that the Republic of Slovenia must assure financial means directly from the state budget, that are intended for urgent treatment of the people of unknown residence, foreigners from the states that have not signed a bilateral treaty with Slovenia, as well as all foreigners and citizens of Slovenia with permanent residence abroad, who are temporarily staying or travelling through Slovenia and are unable to cover the costs of medical treatment. The Article also mentions other persons who are not included into health insurance system (compulsory health insurance) and are not insured by a foreign health insurance provider/agency.

10 Immediate treatment after emergent medical assistance, and nursing (wound dressing), prevention of sudden and fatal deteriorations of chronic diseases or health condition that could lead to the severe damage of respective organs and/or their functions, etc. (Article No. 103, Rules on Compulsory Health Insurance - Pravila obveznega zdravstvenega zavarovanja).

11 Admission Instructions for Outpatients' Departments and Hospitals in Case of an Urgent Medical Treatment, and Financial Assessment of Medical Services, Ministry of Health, July $26^{\text {th }} 2010$. 
procedure for issuing a reimbursement claim for costs of the urgent treatment and as a result, the criteria to successfully conclude this procedure are often almost impossible to meet. Thirdly, the right to urgent treatment was further restricted with the provision that implies personal responsibility of the acting doctor, who is required to sign a statement that the treatment was actually necessary and that the performer of medical assistance would, in case this would prove untrue, reimburse unjustified costs of the treatment. ${ }^{12}$ These reasons contribute to the tendency among healthcare institutions to try to charge for urgent treatment, even in cases when it should be free of charge. This has become a practice predominantly in case of migrants without health insurance and other vulnerable groups, who are unable to defend their rights and interests due to linguistic, social, economic and other impediments (Lipovec Čebron et al. 2015; Pistotnik and Lipovec Čebron 2015; Lipovec Čebron and Pistotnik 2018).

\section{Linguistic and cultural barriers}

Besides the officially recognized Italian, Hungarian and Roma minorities, members of many other ethnic groups reside in Slovenia but do not have a status of recognized ethnic minorities. Since the most numerous are from the former Yugoslavia, many Albanians, Croatians, Montenegrins, Serbs, members of ethnic minorities from Bosnia and Herzegovina and the former Yugoslav Republic of Macedonia live in different parts of Slovene territory (Kržišnik-Bukić 2008; Klopčič et al. 2003). Even if members of ethnic groups that come from the territory of exYugoslavia and speak languages similar to Slovene (e.g. Bosnian, Croatian, Serbian, Macedonian) do not encounter noticeable linguistic and cultural barriers when accessing healthcare facilities, the same is not necessarily true for many other ethnic groups coming from different countries of African and Asian continent as well as Middle East and the states from the territory of ex-Soviet Union.

In the qualitative research, many healthcare workers admitted they face difficulties in communication with people who speak languages unknown to them. As a result, linguistic and cultural barriers arise hindering communication between the healthcare workers and those migrants/refugees who do not understand Slovene. All of this can lead to inadequate access to healthcare services and insufficient healthcare treatment, posing a risk to the patients' safety. Moreover, some of the healthcare workers emphasized that they received no proper training in this field during their studies or during their work in the healthcare institution. Many interlocutors also stressed the absence of professional intercultural mediators or interpreters in health-

12 Amendments to Admission Instructions for Outpatients' Departments and Hospitals in Case of an Urgent Medical Treatment, and Financial Assessment of Medical Services (Popravek navodil za sprejem pacientov... 2010). 
care institutions that would be essential for overcoming different linguistic as well as cultural misunderstandings.

\section{Development of tools/strategies to overcome the barriers}

The above stated shows that the obstacles migrants/refugees face in the Slovene healthcare system derive from different sources. As such, they create an intertwinement of structural and practical barriers, which results in limited or denied access to health treatment. Therefore, in order to overcome such barriers and enable more universal access to healthcare for migrants/refugees, the solutions should involve the development of various steps addressing different levels of the system. Based on previous experiences in other European countries (Verrept 2008; Ingleby et al. 2012; HPH Task Force MFH 2014; Bagaglia et al. 2014, etc.) a series of different tools/strategies were analysed, elaborated and - some of them - implemented as a pilot experiment within the project "Together for Health". In the continuation of the chapter we will describe four of them. It is important to stress that these tools/ strategies should be regarded as the first, and by no means final, steps that would lead to more friendly and inclusive arrangements not just for migrants/refugees but also for other vulnerable groups and population as a whole:

\section{a) Changes of the legislation}

A positive aspect of the Slovene health insurance system is its attempt to include the overall majority of the population since only in that way it can maintain its core principle of solidarity (in sense of "young with old, healthy with sick, rich with poor"). But, as we tried to show in the first part of this chapter, the current arrangement is nevertheless leaving some parts of the population uninsured or with more restricted access to compulsory health insurance. This is characteristic not only for some categories of migrants, but increasingly also for other residents of Slovenia (homeless people, precarious workers etc.). In their case, the systemic (legal and administrative) obstacles to accessing the healthcare system can be overcome only with the expansion of the rights of participation in the compulsory health insurance scheme.

In order to address this issues in the framework of the project "Together for Health" an extensive document (Proposals for Systemic Measures to Facilitate Access to Health Insurance and Health Care for Marginalized Groups) with a series of proposed improvements of Slovene legislation was prepared. The most important measures proposed in this document were: the establishment of the interdisciplinary and interdepartmental team for the monitoring of the access to healthcare system for vulnerable groups as well as for the research and preparation of systemic measures 
aimed at overcoming the barriers in the healthcare system; detection of the number of uninsured persons in Slovenia and the introduction of measures that will reduce their number and respect for the right to urgent treatment free of charge and universally accessible to all people in medical need, regardless of their health insurance status. The proposal included other measures aimed more at specific "vulnerable groups" with the focus of reducing the number of uninsured persons among the weakest segments of the population. In this context, a special measure proposed for the migrant population was to ensure equal access to compulsory health insurance for all categories of migrants and refugees (Pistotnik and Lipovec Čebron 2015).

The document was presented in a series of internal and public meetings (at the Ministry of Health of the Republic of Slovenia, Health Insurance Institute of Slovenia and at various conferences organised by National Institute of Public Health where public health authorities were present) where it received considerable attention, but there is no evidence so far that there will be any systemic improvements in this field. One of the main reasons for this could be that authorities do not follow systematically various changes occurring in the field of access to compulsory health insurance scheme, and instead maintain a persuasion about universally accessible healthcare in Slovenia. Due to lack of systemic effort to recognize that an increasing number of people are having difficulties with entering the healthcare system, many marginalized residents are invisible for different health policies; among others not all uninsured persons are included in national compulsory health insurance statistics. Moreover, none of the national or regional institutes are systematically concerned with their access to healthcare, and healthcare workers are frequently left with no clear guidelines on how to address the patients without insurance or with different scope of health rights (for example on the basis of EU health card, asylum seeker's identification card etc.). To implement at least some of the above mentioned proposals that were presented in the document and to accept the proposals of other initiatives in this field (e.g. Integracijski paket... 2012) would mean firstly to recognize the fact that some segments of Slovene population are left uninsured and secondly, a political will to reorganise compulsory health insurance scheme in a more inclusive manner. However, the trends in the last two decades were leaning towards the diminishing of health rights for a growing number of persons and thus show development in the opposite direction.

\section{b) Introduction of the intercultural mediator}

The term "intercultural mediator" refers to a person who works in healthcare institutions with the aim of overcoming linguistic and culture barriers and increasing responsiveness to the needs of ethnic minority users (Verrept 2008). Other terms (such as "link worker", "health advocate", "health-care interpreter" and "culture broker") are also used to define similar, but not identical, profiles within 
healthcare institutions. These roles vary considerably between different countries and/or projects, ranging from pure language interpreting to culture brokering or providing health education. However, research shows that intercultural mediation and/or interpreting improves communication between users and healthcare professionals, contributes significantly to patient satisfaction and is crucial for providing more culturally sensitive healthcare (Bowen 2001; Angelelli 2008; Valero-Garcés and Matin 2008; Verrept 2008; Schapira et al. 2008; Ingleby et al. 2012; TransKom 2012; Bofulin et al. 2016, etc.). For instance, Hans Verrept (2008: 5) claims that

"the most important of all the improvements is the fact that intercultural mediators facilitate the exchange of correct and detailed information between health staff and patients. This is a consequence not only of mediator's presence in itself, but also of the fact that patients are less inhibited about telling their stories in the presence of the intercultural mediator (and/or the absence of an informal interpreter, e.g. child or spouse)."

As was already mentioned, the interlocutors in the qualitative research we had carried out within the project "Together for Health" stressed the absence of intercultural mediation/interpreting in their healthcare institutions. Unlike in some countries of the European Union, ${ }^{13}$ the Slovene healthcare system doesn't provide any professional intercultural mediation or interpretation. Although many professional interpreters exist, they lack the training for interpreting in a healthcare setting, they are often difficult to reach and their services are too expensive for an average patient. In order to address this important gap, a Declaration concerning the introduction of an intercultural mediation in Slovene healthcare institutions ${ }^{14}$ was prepared and signed by eight governmental and non-governmental organizations that are active in the field of migration and health.

Besides, the findings of the qualitative research revealed also that a larger Albanian-speaking community living in the city of Celje experiences a variety of problems when accessing healthcare services, mostly due to linguistic and cultural barriers. The research specifically emphasized the obstacles that women from this community face. To address some of them, an interdisciplinary team of experts decided to pilot the implementation of intercultural mediation for Albanianspeaking women in a healthcare setting. Implementation was carried out between September and December 2015 at the Health promotion centre in the Community health centre Celje and in family medicine Health station Vojnik (also a part of Community health centre Celje).

13 For instance, in Italy (Farini 2013, 2015; Tomassini 2012), Germany (SpraKum 2017); or Switzerland (TransKom 2012; Panagiotopoulou 2015), see also Gosenca 2017.

14 Available at: http://www.skupajzazdravje.si/media/standard.in.orodje_web.pdf (last access 15 January 2018). 
Despite a restricted time period and a limited number of participants, the results of the evaluation made during the pilot implementation ${ }^{15}$ showed that Albanianspeaking women perceived the presence of the intercultural mediator as extremely important and expressed satisfaction with the mediator's work. Moreover, the pilot implementation of intercultural mediation confirmed that health professionals obtained much more reliable data and that patients were able to better understand health professionals as well as express themselves easier and more directly (Lipovec Čebron et al. 2017).

Good results notwithstanding, this pilot implementation raised many questions that should be taken into consideration in case such services are introduced in other healthcare institutions. Comparable to some EU countries (Gosenca 2017), the introduction of an intercultural mediator discussed here was project-based, which meant that the mediator was introduced for a short period of time, for a limited number of patients and only for preventive activities in two Slovene healthcare institutions. Thus we had only touched upon the problem of a lack of adequate mediation/interpretation services for foreign speaking patients and in no way addressed it in a satisfactory manner. Namely, similarly to practice in certain EU countries (ibid.), the experience in Celje indicates that, in order to provide adequate service in the future, there is a significant need to clearly define the tasks of an intercultural mediator as well as to organize a long-term training for intercultural mediators (in the field of medical terminology, interpreting etc.) and to enable their professionalization (certification) in Slovenia.

\section{c) Training in cultural competency for healthcare workers}

Similar to intercultural mediation, cultural competency is also a rather new concept in a Slovenian context. Cultural competence was developed in certain multiethnic countries (e.g. Australia, Canada, Great Britain, USA) in the middle of the 20th century as an approach that helps to understand and interact with persons from cultures, ethnic or social groups other than one's own. The concept was first promoted by health care professionals who recognized the importance of being

15 Evaluation was carried out in both healthcare facilities in which intercultural mediation was implemented. Firstly, it was focused on three health education workshops, organized by the Health promotion centre Celje, where the intercultural mediator was present immediately after each workshop. Participants were asked to complete a questionnaire in Albanian evaluating the program: all questions were closed, with only a limited range of answers. Secondly, a similar questionnaire was used for the evaluation of individual preventive check-ups in family Health station Vojnik that were also carried out with a help of the mediator. Likewise the questionnaires were distributed immediately after each examination. The analysis of questionnaires was supplemented with interviews conducted with key persons involved in the implementation of intercultural mediation (intercultural mediator and healthcare workers). 
able to communicate effectively with migrant workers and other migrants/refugees. However, the notion of cultural competence is not focused exclusively on migrant/ refugee patients, since it includes the sensible treatment of all persons who, due to their social, economic or cultural background, encounter problems with access to healthcare institutions or within them (Betancourt et al. 2002). Research shows that culturally competent healthcare has many advantages and a significant impact on health outcomes and well-being of everyone involved in a health treatment. On one hand, it gives users more confidence and facilitates their contacts with health professionals, increases their compliance with medical advice, decreases the frequency of consequences of improper use of medicines and improves the health literacy of the population. On the other hand, health workers make fewer mistakes in determining diagnoses, provide better quality health care and, in general, carry out the work more effectively (Beach et al. 2008; Lehman et al. 2012; Bofulin et al. 2016).

As our interlocutors emphasized, during their studies (at medical faculties and faculties of health sciences) as well as during their professional careers, there was no specific training that would prepare healthcare workers for work in a culturally and ethnically diverse healthcare setting. As a response to this lack that was commonly raised in the interviews during the qualitative research, an interdisciplinary team designed and organized a 20-hour cultural competency training that took place between January and July 2015 in three Slovene healthcare centres (Vrhnika, Sevnica, Celje), and in which 51 healthcare workers participated. For the purpose of this training, a handbook titled Cultural Competency and Healthcare. Handbook for Developing Cultural Competency for Healthcare Workers was published. ${ }^{16}$ The training consisted of interactive lectures and workshops on different topics (including migration and health, migrants'/refugees' access to healthcare and other obstacles that migrants/refugees face in healthcare institutions) and was carried out by an interdisciplinary team of medical anthropologists, sociologists, social workers, medical doctors and researchers in public health. It is important to stress that, in the process of the development of the training, the project team analysed educational models from different countries, but the final curriculum was organized as an independent and locally-sensitive model of training.

Although the training was evaluated ${ }^{17}$ as useful and important for a more sensitive approach towards users from different cultural and social backgrounds, there are several limitations to it. Firstly, among different profiles of health workers participating in the training, no medical doctor attended. Secondly, since the training

16 The handbook is available in Slovene language: http://www.nijz.si/sl/publikacije/kulturne-kompetence-in-zdravstvena-oskrba-prirocnik-za-razvijanje-kulturnih-kompetenc (last access 15 January 2018).

17 Evaluation took place at the end of the training as a group discussion as well as through questionnaires that were distributed after each day of training. 
lasted only 20 hours, many topics couldn't be presented or discussed in-depth and thirdly, the training was, for practical reasons, carried out in a classroom and thus without the possibility of developing skills in everyday practice.

In the future, it would be essential to integrate the contents of this and other similar trainings into undergraduate and postgraduate education programmes for health professionals. In this way, a necessary continuity of such education could be provided, but at the same time certain contents could be upgraded with more practical work that was lacking in pilot training. Moreover, in addition to the developed training in cultural competency for practising health professionals that covers basic topics in this field, it seems meaningful to put more attention on supplementary education on specific topics (for example connected with certain groups within the population, e.g. healthcare rights for unaccompanied minors, LGBTIQ etc. or with specific issues, e.g. perinatal care in different cultural contexts, genital mutilation and reproductive health etc.) as is the practice in some EU countries (Bagaglia et al. 2014).

d) Standard for equity in healthcare for migrants and other "vulnerable groups"

As stated in the introduction of the chapter, experiences in different EU countries show that "health organizations find themselves increasingly faced with the specific vulnerability of migrants who run a greater risk of not receiving adequate service in diagnosis, care and prevention because of their minority status, their socioeconomic position, communication difficulties and lack of familiarity with health systems" (HPH Task Force MFH 2014: 12). Therefore, it seems essential that a response to these problems is part of a larger institutional response. To further address the issue of all-embracing inequity in healthcare detected in the qualitative research, a project team translated the Standard for Equity in Health Care for Migrants and Other "Vulnerable Groups" and adapted it to the Slovene context ${ }^{18}$ (Chiarenza et al. 2016). The Standard was developed by Task Force on Migrant-Friendly and Culturally Competent Healthcare (TF MFCCH) and is aimed at monitoring and measuring equity in healthcare for certain populations as well as at "providing the opportunity for staff and services to question what they do, why they do it, and whether it can be done better" (HPH Task Force MFH 2014: 7). The preliminary standards have been pilot-tested and evaluated by 45 healthcare organizations from 12 countries (including Slovenia) in 2012. A part of this Standard is a self-assessment tool for healthcare institutions with which they are encouraged to evaluate the level of equity and inclusion that they are providing in relation to migrants/refugees and other marginalized groups (ibid.). It is composed of a set of questions in the fields

18 The Standard is available at: http://www.skupajzazdravje.si/media/standard.in.orodje_web.pdf (last access 15 January 2018). 
ranging from equity in policy and management to equity in care services and promotion of health.

Although the Standard and Self-assessment tool were conceptually and linguistically adapted to the Slovene context and were promoted in public and internal meetings with the authorities, no significant interest for it was shown from healthcare institutions in Slovenia. As stated above, Slovene authorities do not (fully) acknowledge the increasing number of residents who have limited access to the healthcare system in Slovenia. Since this problem remains neglected on a national level, it is not surprising that no motivation for a self-evaluation on this topic exists by health institutions at a local level. The experience with the implementation of this tool therefore opened a following question: if the optional use of the Standard and Self-assessment tool did not give the predicted results, what outcomes could we expect if it were to be introduced as an obligatory practice?

\section{Conclusion}

We stated at the beginning of the chapter that the "deterioration" of once almost universal public healthcare system in Slovenia is most visible in the obstacles migrants/refugees encounter in their search for health. Besides the obstacles analysed here there are various others, for example health issues related to migrants/ refugees social status and the level of poverty; to work conditions and exposures to different health risks; to psychological problems connected with discrimination and lack of successful integration policies etc. Different medical anthropologists and other experts (Horton 2004; Fassin 2014; Castañeda et al. 2015; Flynn et al. 2015 etc.) had extensively researched these and other structural factors that directly or indirectly cause the ill health of migrants'/refugees' population. Among the most explored is certainly the question of access to healthcare. However, far less academic attention is dedicated to the research of the tools/strategies with which these obstacles could be or are addressed and/or surmounted - little is known about the methodology used to implement them, evaluation of the process of the implementation or the results that different approaches brought. With this in mind, we tried to present in our contribution the activities of the project "Together for Health".

In conclusion, it is important to stress some final considerations. Firstly, there is a common temptation to simply "copy-paste" a model of best practice from one region to another. In many cases, this approach shows to be narrow-minded and inefficient. Our anthropological knowledge prevented us from making such a mistake and all four approaches described above were carefully prepared according to local needs and expectations. Secondly, the role of anthropologists in the interdisciplinary team seems to be indispensable not only for an understanding of a local context, which is needed for the pilot implementation of a certain approach, but 
also in all other phases of the project work: from introducing qualitative methods as the basis to design and evaluate the project's outcomes to choosing a specific group and location for a pilot implementation (e.g. Albanian-speaking women in the city of Celje). Thirdly, during the last three years of work in this field, we have learned that improvements should always include a series of possible approaches, ranging from those that address changes in national legislation and organisation of healthcare system to those that are focused on a local level and respect specific needs of a particular community. Namely, the project has shown that intercultural mediation cannot be regarded as an efficient tool for addressing linguistic and cultural obstacles without the extensive training of healthcare workers in cultural competency and without the active engagement of healthcare institutions on all levels in diminishing of health inequities among the population. On the basis of the positive results of the project "Together for Health" in all three pilot environments, a nation-wide project was planned, which is expected to include 25 environments from 2018 onwards. The future will show what kind of new challenges this larger and upgraded project will bring.

Lastly, as mentioned above one of the biggest drawbacks of our work was - as is the case with most projects - that it was short-lived and not aimed at systemic changes in the healthcare system. Thus we can rightly ask ourselves: what is the meaning of such projects? Who benefits from them? Do they have any lasting influence? Short-term, highly specialized projects without long-term effects have become part of daily life and their normalized inefficiency seems to be just another neoliberal strategy for maintaining the status quo in society through mediation of social tensions and potential conflicts. However, the question remains: do we, as researchers, have the possibility and motivation to change this trend? 


\section{REFERENCES}

Admission Instructions for Outpatients' Departments and Hospitals in Case of an Urgent Medical Treatment, and Financial Assessment of Medical Services. Ministry of Health. July $26^{\text {th }} 2010$.

Albreht Tit, Rade Pribaković Brinovec, Dušan Jošar, Mircha Poldrugovac, Tatja Kostnapfel, Metka Zaletel, Dimitra Panteli and Anna Maresso. 2016. "Slovenia. Health System Review". Health Systems in Transition 18/3: 1-207.

Angelelli, Claudia. 2008. "The Role of the Interpreter in the Health Care Setting. A Plea for a Dialogue between Research and Practice". In Crossing Borders in Community Interpreting. Definitions and Dilemmas. Carmen Valero-Garcés and Anne Martin, eds. Amsterdam, Philadelphia: John Benjamins, 147-164.

Bagaglia, Carlotta, Sabrina Flamini, Maya Pellicciari and Chiara Polcri. 2014. Mutilazioni genitali e salute riproduttiva [Genital Mutilation and Reproductive Health]. Perugia: Fondazione Angelo Celli.

Beach, Mary Catherine, Lisa A. Cooper and Saha Somnath. 2008. "Patient Centeredness, Cultural Competence and Healthcare Quality". Journal of National Medical Association 100/11: 1275-1285.

Betancourt, Joseph R., Alexander R. Green and J. Emilio Carrillo. 2002. Cultural Competence in Health Care. Emerging Frameworks and Practical Approaches. Field Report. New York: The Commonwealth Fund.

Bofulin, Martina and Romana Bešter. 2010. "Enako zdravstvo za vse? Imigranti v slovenskem zdravstvenem sistemu" [Equal Health Care for All? Immigrants in the Slovenian Health System]. In Državljani tretjih držav ali tretjerazredni državljani? Integracija državljanov tretjih držav v Sloveniji. Mojca Medvešek and Romana Bešter, eds. Ljubljana: Inštitut za narodnostna vprašanja, 270-311.

Bofulin, Martina, Jerneja Farkaš Lainščak, Karmen Gosenca, Ajda Jelenc, Marjeta Keršič Svetel, Uršula Lipovec Čebron, Sara Pistotnik, Juš Škraban and Darja Zaviršek. 2016. Kulturne kompetence in zdravstvena oskrba. Priročnik za razvijanje kulturnih kompetenc zdravstvenih delavcev [Cultural Competences and Health Care. A Handbook for Developing Cultural Competences of Health Care Professionals]. Ljubljana: Nacionalni inštitut za javno zdravje.

Bombač, Lea, Uršula Lipovec Čebron, Sara Pistotnik, Andreja Turk Šverko, Andrej Trojar, Simona Repar Bornšek, Nina Sodja, Aida Hadžiahmetović, Helena Liberšar and Erika Zelko. 2017. "Zdravstvena obravnava prosilcev in prosilk za mednarodno zaščita v Sloveniji” [Health Care of Applicants for International Protection in Slovenia]. In X. Zadravčevi dnevi. Zbornik predavanj. Erika Zelko, ed. Ljubljana: Zavod za razvoj družinske medicine, 28-36.

Brovč, Majda, Janja Ahčin, Marinka Šlajpah and Danica Rotar-Pavlič. 2009. "Ekonomski imigranti v Sloveniji in njihova stališča o boleznih. Kvalitativna raziskava" [Economic Immigrants in Slovenia and Their Attitudes towards Ill Health. A Qualitative Study]. Zdravstveno varstvo 48/1: 26-32. 
Bowen, Sarah. 2001. Language Barriers in Access to Health Care. Ottawa: Health Canada.

Buzeti, Tatjana, Janet Klara Djomba, Mojca Gabrijelčič Blenkuš, Marijan Ivanuša, Helena Jeriček Klanšček, Nevenka Kelšin, Tatjana Kofol Bric, Helena Koprivnikar, Aleš Korošec, Katja Kovše, Jožica Maučec Zakotnik, Barbara Mihevc Ponikvar, Petra Nadrag, Sonja Paulin, Janja Pečar, Silva Pečar Čad, Mateja Rok Simon, Sonja Tomšič, Polonca Truden Dobrin, Vesna Zadnik and Eva Zver. 2011. Neenakosti v $z$ dravju $v$ Sloveniji [Inequalities in Health in Slovenia]. Ljubljana: Inštitut za varovanje zdravja.

Castañeda, Heide, Seth M. Holmes, Daniel S Madrigal, Maria-Elena De Trinidad Young, Naomi Beyeler and James Quesada. 2015. "Immigration as a Social Determinant of Health". Annual Review of Public Health 36: 375-392.

Chiarenza, Antonio, Jerneja Farkaš Lainščak and Uršula Lipovec Čebron, eds. 2016. Standard za zagotavljanje enakosti $v$ zdravstveni oskrbi “ranljivih" skupin in orodje za samoocenjevanje zdravstvenih ustanov [Standard for Equity in Health Care for Migrants and Other Vulnerable Groups. Self-Assessment Tool for Pilot Implementation]. Ljubljana: Nacionalni inštitut za javno zdravje.

Farini, Federico. 2013. "Interpreting and Intercultural Mediation in Italian Healthcare Settings". Journal of Intercultural Communication 33: 1-19.

Farini, Federico. 2015. "Talking Emotions in Multilingual Healthcare Settings. A Qualitative Study of Interpreted-Mediated Interaction in Italian Hospitals”. The Interpreters' Newsletter 20: 123-128.

Farkaš, Jerneja, Majda Pahor and Lijana Zaletel-Kragelj. 2011. "Self-Rated Health in Different Social Classes of Slovenian Adult Population. Nationwide Cross-Sectional Study". International Journal of Public Health 56: 45-54.

Fassin, Didier. 2004. "Social Illegitimacy as a Foundation of Health Inequality. How the Political Treatment of Immigrants Illuminates a French Paradox". In Unhealthy Health Policy. A Critical Anthropological Examination. Arachu Castro and Merrill Singer, eds. Walnut Creek etc.: AltaMira Press, 203-204.

Flynn, Michael A., Donald E. Eggerth and Jeffrey C. Jacobson. 2015. "Undocumented Status as a Social Determinant of Occupational Safety and Health. The Workers' Perspective". American Journal of Industrial Medicine 58/11: 1127-1137.

Gosenca, Karmen. 2017. Medkulturna mediacija. Priložnost za boljšo zdravstveno oskrbo [Intercultural Mediation. An Opportunity for Better Health Care]. Unpublished MA thesis. Ljubljana: Oddelek za etnologijo in kulturno antropologijo Filozofske fakultete v Ljubljani.

Holtz, Timothy, Seth M. Holmes, Scott Stonington and Leon Eisenberg. 2006. "Health is Still Social. Contemporary Examples in the Age of the Genome". Plos Med 3: 1663-1666.

Horton, Sarah. 2004. “Different Subjects. The Health Care System's Participation in the Differential Construction of the Cultural Citizenship of Cuban Refugees and Mexican Immigrants". Medical Anthropology Quarterly 18/4: 472-489. 
HPH Task Force MFT. 2014. Standard for Equity in Health Care for Migrants and Other Vulnerable Groups. Self-Assessment Tool for Pilot Implementation. Reggio Emilia: Regional HPH Network of Emilia-Romagna.

Ingleby, David. 2017. Migrant Integration Policy Index. Health Strand. Country Report Slovenia. Brussels: IOM MHD RO Brussels.

Ingleby, David, Antonio Chiarenza, Walter Deville and Ioanna Kotsioni, eds. 2012. Inequalities in Health Care for Migrants and Ethnic Minorities, 2. COST Series on Health and Diversity. Antwerp: Garant Publishers.

Integracijski paket za brezposelne migrante, prosilce za azil in begunce [Integration Package for Unemployed Migrants, Asylum Seekers and Refugees]. Unpublished report. 2012. Ljubljana: Zveza svobodnih sindikatov Slovenije.

Jazbinšek, Simona and Tina Palaić. 2009. "Zdravje - človekova pravica? Prosilke in prosilci za mednarodno zaščito" [Health - Human Right? Applicants for International Protection]. Casopis za kritiko znanosti 37/238: 154-162.

Kraševec Ravnik, Ema. 1996. "Zdravje socialnoogroženih in brezposelnih" [Socially Deprived and Unemployed Person' Health]. In Varovanje zdravja posebnih družbenih skupin v Sloveniji. Ema Kraševec Ravnik, ed. Ljubljana: Inštitut za varovanje zdravja in Slovenska fondacija, 43-72.

Kržišnik-Bukić, Vera. 2008. "Narodnomanjšinsko vprašanje v Sloveniji po razpadu Jugoslavije. O družbeni upravičenosti priznanja statusa narodnih manjšin Albancem, Bošnjakom, Črnogorcem, Hrvatom, Makedoncem in Srbom v Republiki Sloveniji s predlogi za urejanje njihovega narodnomanjšinskega položaja" [National-Minority Question in Slovenia after the Breakdown of Yugoslavia. On the Justification of the Acknowledgment of the National Minority Status for the Albanians, Bosniacs, Croats, Macedonians, Montenegrins and Serbs in the Republic of Slovenia, along with the Model Managing Proposals]. Razprave in gradivo 56-57: 120-156.

Klopčič, Vera, Miran Komac and Vera Kržišnik-Bukić. 2003. Albanci, Bošnjaki, Črnogorci, Hrvati, Makedonci in Srbi v Republiki Sloveniji (ABČHMS v RS). Položaj in status pripadnikov narodov nekdanje Jugoslavije v Republiki Sloveniji [Albanians, Bosniacs, Montenegrins, Croats, Macedonians and Serbs in the Republic of Slovenia (ABMCMS in RS). Position and Status of Nationals of former Yugoslavia in the Republic of Slovenia]. Ljubljana: Inštitut za narodnostna vprašanja. http://www. inv.si/DocDir/Publikacije-PDF/Raziskovalna\%20porocila/Raziskava_Polozaj_ in_status_pripadnikov_narodov_nekdanje_Jugoslavije_v_RS.pdf (last access 15 January 2018).

Leskošek, Vesna. 2013. "Vpliv paradigmatskih sprememb" [The Influence of Paradigmatic Changes]. In Revšcina zaposlenih. Vesna Leskošek, Simona Smolej, Lilijana Rihter, Ružica Bošković, Barbara Kresal and Maja Breznik, eds. Ljubljana: Sophia, 149170.

Leskošek, Vesna. 2016. "Migracije in dostop do socialnih pravic v EU in Sloveniji" [Migrations and Access to Social Rights in the EU and Slovenia]. Dve domovini / Two Homelands 43: 91-102. 
Lipovec Čebron, Uršula. 2010a. "The Construction of a Health Uninsurant. People without Medical Citizenship as Seen by Some Slovene Health Workers". Studia ethnologica Croatica 22: 187-212.

Lipovec Čebron, Uršula. 2010b. "Slepa pega evropskega zdravstva. Analiza nekaterih vidikov zdravja migrantov" [Blind Spot of the European Health Care. Analysis of Some Aspects of Migrant Health]. In Migranti v Sloveniji. Med integracijo in alienacijo. Karmen Medica, Goran Lukič and Milan Bufon, eds. Koper: Univerza na Primorskem, Znanstveno-raziskovalno središče, 57-81.

Lipovec Čebron, Uršula, Marjeta Keršič-Svetel and Sara Pistotnik. 2015. Zdravstveno marginalizirane skupine. Prepreke, ovire, nepremostljivi zidovi do zdravja [Health Marginalized Groups. Barriers, Obstacles, Insurmountable Walls to Health]. Unpublished report of the project Together for Health. Ljubljana: Nacionalni inštitut za javno zdravje.

Lipovec Čebron, Uršula, Marjeta Keršič-Svetel and Sara Pistotnik. 2016. "Zdravstveno marginalizirane - 'ranljive' skupine. Ovire v dostopu do sistema zdravstvenega varstva in v njem" [Health Marginalized - "Vulnerable" Groups. Barriers to Access the Healthcare System and Inside It]. In Ocena potreb uporabnikov in izvajalcev preventivnih programov za odrasle. Ključni izsledki kvalitativnih raziskav in stališča strokovnih delovnih skupin. Jerneja Farkaš-Lainščak, ed. Ljubljana: Nacionalni inštitut za javno zdravje, 14-25.

Lipovec Čebron, Uršula, Sara Pistotnik, Simona Jazbinšek and Jerneja Farkaš Lainščak. 2017. "Evaluation of the Implementation of Intercultural Mediation in Preventive Healthcare Programs in Slovenia". Public Health Panorama 3/1: 114-119.

Lipovec Čebron, Uršula and Sara Pistotnik. 2018. "(Im)Mobile Populations and Health Rights. Accessing the Healthcare System in Slovenia". In Health and Care (Im)Mobilities. Cecilia Vindriola-Padros, Ginger A. Johnson and Anne E. Pfister, eds. New York, Oxford: Berghahn. In print.

Lehman, Dawn, Paula Fenza and Linda Hollinger-Smith. 2012. Diversity \& Cultural Competency in Health Care 28 Settings. Mather LifeWays Orange Paper. https://www. matherlifewaysinstituteonaging.com/wpcontent/uploads/2012/03/diversity-andcultural-competency-in-health-care-settings.pdf (last access 12 April 2014).

Marmot, Michael and Richard G. Wilkinson. 2006. Social Determinants of Health. Oxford: Oxford University Press.

MIPEX. 2015. MIPEX - Country Report for EQUI-HEALTH. Brussels: International Organisation for Migration. http://www.mipex.eu (last access 3 December 2017).

Panagiotopoulou, Akrive Irene. 2015. Research Report on Intercultural Mediation for Immigrants in Switzerland. Olympic Training and Consulting Ltd. http://www. mediation-time.eu/images/TIME_O1-A1_National_Report_Switzerland.pdf (last access 15 January 2018).

Pistotnik, Sara and Uršula Lipovec Čebron. 2015. Predlogi sistemskih ukrepov za lažji dostop do zdravstvenega zavarovanja in do zdravstvenega varstva za odrinjene skupine [Proposals for Systemic Measures to Facilitate Access to Health Insurance and 
Health Care for Marginalized Groups]. Upublished report. Ljubljana: Nacionalni inštitut za javno zdravje.

Popravek navodil za sprejem pacientov $v$ zdravstveno obravnavo v ambulantah nujne medicinske pomoči oziroma v sprejemnih ambulantah $v$ bolnišnicah ter za obračun opravljenega dela [Amendments to Admission Instructions for Outpatients' Departments and Hospitals in Case of an Urgent Medical Treatment, and Financial Assessment of Medical Services]. 2010. Ljubljana: Ministrstvo za zdravje.

"Pravila obveznega zdravstvenega zavarovanja" [Rules on Compulsory Health Insurance]. Uradni list RS 30/2003.

Rajgelj, Barbara. 2012. "Vpliv delovnopravnega, državljanskega indružinskopravnega statusa na neenako obravnavo v zdravstvenem zavarovanju" [The Effects of Labour, Citizenship and Family Status on the Unequal Treatment in Health Insurance]. Zdravstveno varstvo 51: 43-52.

Rostila, Mikael. 2013. Social Capital and Health Inequality in European Welfare States. New York: Palgrave Macmillan.

SpraKum. 2017. Practical Examples. Asylum Seekers. Wuppertal: TransKom. http://www. transkom.info/pdf/Dok2.pdf (last access 15 January 2018).

Schapira, Lidia, Erika Vargas, Renzo Hidalgo, Marilyn Brier, Lourdes Sanchez, Karin Hobrecker, Thomas Lynch and Bruce Chabner. 2008. "Lost in Translation. Integrating Medical Interpreters into the Multidisciplinary Team". Oncologist 13: 586-592.

Tomassini, Elena. 2012. "Healthcare Interpreting in Italy. Current Needs and Proposals to Promote Collaboration between Universities and Healthcare Services". The Interpreters' Newsletter 17: 39-54.

TransKom. 2012. Comparative Study on Language and Culture Mediation in Different European Countries. Wuppertal: EQUAL EP TransKom - gesund\&sozial.

Valero-Garcés, Carmen and Anne Martin, eds. 2008. Crossing Borders in Community Interpreting. Definitions and Dilemmas. Amsterdam: Benjamin Translation Library.

Verrept, Hans. 2008. "Intercultural Mediation. An Answer to Health Care Disparities?”. In Crossing Borders in Community Interpreting. Definitions and Dilemmas. Carmen Valero-Garcés and Anne Martin, eds. Amsterdam, Philadelphia: Benjamins, 187201. A slightly modified form of the article is available at: https://www.ausl.re.it/ sites/default/files/H.Verrept\%20Intercultural\%20mediation\%20-\%20an\%20 answer\%20to\%20health\%20care\%20disparities.pdf (last access 15 January 2018).

"Zakon o zdravstvenem varstvu in zdravstvenem zavarovanju (ZZVZZ-UPB3)" [Health Care and Health Insurance Act]. 2006. Uradni list RS 72/2006. 